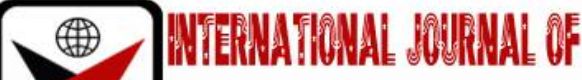

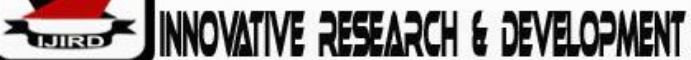

ISSN 2278-0211 (Online)

\section{The Effect of Sustainability Reporting on Profitability of Quoted Consumer Goods Manufacturing Firms in Nigeria}

\author{
Ofoegbu, Grace Nyereugwu \\ Senior Lecturer, Department of Accountancy \\ University of Nigeria, Enugu Campus, Enugu State, Nigeria \\ Asogwa, Chinedu Ugonma \\ Lecturer, Department of Accountancy, \\ Nnamdi Azikiwe University, Nigeria
}

\begin{abstract}
This study aims to: examine the effect of both (i) social disclosures, (ii) environmental disclosures, (iii) economic disclosures on the profitability of listed consumer goods manufacturing companies in Nigeria. The sample of this study comprises of 15 out of 23 consumer goods manufacturing companies in Nigeria based on secondary data from 2009 to 2018. The hypotheses were tested with t-test statistics. The results suggest that economic and social performance disclosures have an insignificant positive impact on both earnings per share and return on equity, whereas, environmental disclosures have a strong positive and significant effects only on earnings per share. Furthermore, sustainability reporting had a positive and significant impact on the profitability of selected companies. It was recommended that companies publish useful sustainability reports as this would improve their profitability.
\end{abstract}

Keywords: Sustainability reporting, profitability, consumer goods manufacturing companies, Nigeria

\section{Introduction}

One of the major problems facing the world today is the issue of adverse climate change. Nigeria is not exempted from this negative trend, with severe drought in the north, floods, and erosion in the south, oil spillages, and gas flaring in the Niger Delta area of Nigeria. These events are inimical to the environment and also affect human beings living in such an environment. Hence issues such as environmental pollution, waste materials, product quality and safety, the increasing rate of workers lay off; work-related hazards and stress, employee rights and social responsibility, labour unrest have gained importance and have been a severe source of concern to the government and the society at large. The economic and technological contributions of business have been criticized for causing social and environmental problems over time. Therefore, to control these problems, it has become pertinent to establish sustainability culture in businesses. With the concept of sustainability, companies are expected by the global market to give a report that included their social, economic and environmental consequences; besides the traditional financial statements that focus on profit and financial position (Dibia \& Onwuchekwa, 2015; Zeynep \& Fikret. 2019). It is hoped that such a practice would make organizations pay more attention to the impact of their operations on the environment. Because more and more investors are interested in strategies that consider relevant environmental, social and governance (ESG) factors, an approach known broadly as sustainable investing. Investors use environmental, social and governance data to evaluate the sustainability context of investments (Ariel \& Giulia, 2019). A study by Harvard Business Review in found out that companies that developed a process of managing, measuring, and communicating performance on ESG issues in the early 1990s outperformed a carefully matched control group over the next 18 years (Robert \& Svetlana, 2019). Another study by Nordea Equity Research (2017) reported that from 2012 to 2015, the companies with the highest ESG ratings outperformed the lowestrated firms by as much as 40\%. According to the Bank of World Economic Forum (2020) reported that firms with a better ESG record than their peers produced a higher three-year return. All these demonstrated a relationship between sustainability disclosure and firm performance. The question is, has such research been carried out in Nigeria to establish such a relationship between sustainability reporting and company performance? The studies carried out in developed countries cannot be generalized to include emerging economies such as Nigeria. Most prior investigations in Nigeria focused on the level of sustainability reporting (see Owolabi et al. 2016; Okwuosa \& Amaeshi 2018). Other studies that engaged in sustainability and performance of corporate bodies in Nigeria worked between 2012 and 2016 (see Akabom et. at 2018; Nnamani et at 2017). Moreover, a study by Ali, Haitham and Nilesh (2018) indicated that there is a gap in literature on the subject of corporate sustainability impact on financial performance in developing economies. They call for more publications from scholars in these countries. Therefore, the need arises that a research effort should be made to examine the effect of the three dimensions of sustainability (social, economic, and environmental) reporting on the profitability of Nigerian manufacturing firms extending the date from 2009 to 2018. 
Therefore, the objective of this study is to determine the impact of sustainability reporting on the profitability of listed consumer goods manufacturing companies in Nigeria. The specific goals were to; examine the effect of social disclosures on the profitability of listed consumer goods manufacturing companies; determine the impact of environmental disclosures on the profitability of listed consumer goods manufacturing companies; ascertain the effect of economic disclosures on the profitability of listed consumer goods manufacturing companies in Nigeria.

The rest of the paper is organized as follows; Section II provides a review of related literature, hypotheses development and theoretical framework; Section III presents the methodology, and Section IV presents and analyses the data collected, and summary of findings, conclusion and recommendations of the study are in Section V.

\section{Review of Related Literature}

\subsection{Sustainability Reporting}

Sustainability reporting is the term which is widely used to communicate the companies' effect on social, environmental, and economic performance. Such report is disseminated and published to fulfil the needs of a wide range of stakeholders such as investors, creditors, employees, customers, suppliers, governments, activist groups, and the general public. It is recently used to cover the disclosure of a company's commitment to sustainable practice (Burhan \& Rahmanti, 2012). Sustainability reporting is a systematic tool to gather and present sustainability information for the management process and to stakeholders which include apart from the ones already mentioned, local communities, NGOs, financial analysts (INTOSAI WGEA, 2013).

Sustainability reporting started with private sector companies in developed countries. It, however, always has global links. For instance, the transparency of supply chains and responsible business, such as respect for the society and environment are also essential for less developed countries. There has, however, been a new wave of interest in sustainability reporting after the financial crises started in 2008, as there have been calls for more extensive transparency, better long-term considerations and highlighting of systemic risks. Investors are increasingly seeking to invest in companies that follow good sustainability practices (Burhan \& Rahmanti, 2012; INTOSAI WGEA, 2013).

Sustainability reporting requires a systematic presentation of sustainability data for comparison with the past and progress concerning selected targets. Sustainability information includes both financial and non-financial information. Financial data has a direct link with the financial accounting system and is expressed in monetary units. Non-financial information means that it is not presented in monetary terms and is not based on an accounting standard. Non-financial information can be both quantitative, such as tons (or units) of greenhouse gas, or qualitative, such as governance processes, the reputation of an organization or the organization's impact on the state of biodiversity (NIVRA, 2009 as cited in INTOSAI WGEA, 2013).

\subsection{Sustainability Reporting in Nigeria}

The Companies and Allied Matters Act of 1990 Cap C20 2004 is the guiding law for companies in Nigeria. It regulates how companies are conducted and statutory reports published by companies. However, the Act focuses mainly on financial reporting. No provision was made for sustainability reporting in the Act. In trying to improve environmental disclosure by companies, the Federal Government formulated several environmental laws through the ministry of Environment and Natural Resources. Examples of such laws are (Leyira, Uwaoma \& Olagunji, 2011).: Federal Environmental Protection Agency Act of 1988; The National Environmental Protection (Effluent Limitation) Regulation; National Environmental Protection (Pollution Abatement in Industries and Facilities Generating Waste) Regulation; National Environmental Protection (Management of Solid and Hazardous Waste) Regulation; Environmental Impact Assessment Act of 1992; and Harmful Waste Act of 1988 These laws aimed at (Adediran \& Alade, 2013).; Restricting the release of a toxic substance into the environment. These Acts mainly established the standards which industries and facilities generating waste must meet; requiring organizations to develop contingency plans for handling unusual and accidental discharge and developing strategies for waste reduction; as well as install facilities capable of reducing or eliminating pollution arising from their production activities. The laws also established the maximum limits of effluent parameter discharge allowed into the air, streams, rivers, drains, and ground.

In the absence of any sustainability code, Nigeria adopted ISO 26000 in 2013, which is the NIS: ISO 26000. The ISO 26000 is a standard on social responsibility launched by the International Organization for Standardization in 2110 . It is aimed at giving guidance to organizations on how to make their operations sustainable. It encourages organisations to be ethical and transparent in their dealing thereby contribute to the welfare of the society in which they exist). It requires organizations to conform to global best practice while they take into account the social, environment, laws, culture, as well as the political and economic environment in which they find themselves (International Organization for Standardization,2010). One of the purposes for its adoption in Nigeria was for ensuring that charity and philanthropic activities of many corporate organizations are well documented in their reporting in line with global sustainability reporting standards. Despite this adoption, sustainability reporting in Nigeria was still unregulated and voluntary (Aondoakaa, 2015), and many corporate organisations do not present their report to reflect their suitability impact on society.

However, in January 2019, Nigeria launched its first sustainability code for private sector companies operating in Nigeria through the Securities and Exchange Commission (SEC). While some firms believe, account for, and render sustainability report, others feel reluctant to embrace sustainability reporting because they think that it is not aligned to profit maximization (Whetman, 2018). The result of this paper could help in convincing firms that sustainability practices constitute a potential for long-term value creation from which shareholders can benefit (Ching, Gerab \& Toste, 2017). 


\subsection{Empirical Review}

Many authors have empirically investigated the effect of sustainability disclosure on the performance of firms though there is a dearth of literature on it in Nigeria. Some revealed positive and others the negative relationship between sustainability reporting and firm's performance. This part of the work will fist review those researched that has positive effect before those with a negative impact on a firm's performance.

Whetman (2018) examined the impact of sustainability reporting on the firm's profitability. The study focused on 95 publicly traded firms from various sectors of the economy for the period $2015-2016$. The work revealed a positive and significant effect of sustainability reporting on a firm's return on equity, return on assets, and profit margin in the subsequent year. The author further reported that the result applied only to firms with low institutional ownership and concluded that co-prate sustainability reporting represents an effective substitute for monitoring by institutional investors. Laskar (2018) did a similar study on the impact of corporate sustainability reporting on firm's performance in Asia using a total of 111 nonfinancial firms from four Asian countries namely Japan, South Korea, Indonesia and India. The study adopted content analysis to determine the disclosure score of sustainability performance based on Global Reporting Initiative (GRI) format. The regression result of the study indicated a significant positive association between sustainability reporting and firm's performance. The study further found that the relative impact of sustainability reporting on firm performance was more in developed countries than in developing countries of Asia.

Buallay (2019) carried out a study on sustainability reporting and firm's performance comparing the result from the listed banking and manufacturing sectors of eighty 80) economies of the globe. The indices for sustainability were environmental, social, and governance (ESG) and their impact on operational, financial and market performances were tested. The finding showed a positive effect on operational, financial and market performance in the manufacturing firms. However, ESG has a negative impact on the operational, financial and market performance in the banking sector.

Uwuigbe (2018) carried a study of sustainability reporting and firms performance: A bi-directional approach focusing on Deposit Money Banks in Nigeria. Sustainability reports of the selected firms were analysed through the use of content analysis and coded to obtain the sustainability disclosure index. The finding revealed a bi-directional relationship between sustainability reporting and firm performance of quoted Deposit Money Banks (MDB) in Nigeria. In Malaysia, Nur, Boon and Tze (2016) established that economic, social and environmental sustainability reporting is positively associated with financial performance measured using Return of Assets and Return on equity. The study was on sustainability reporting, and financial performance of Malaysian Public Listed companies and content analysis was used based on some sentences and GRI indicators.

The following other studies indicated a negative relationship between sustainability reporting and firm performance. Ching, Gerub and Toste (2017) carried out a survey of the quality of sustainability reports and corporate financial performance using Brazilian listed companies. The period of this study was from 2008 t0 2014 and limited to only those companies included in the corporate sustainability index (ISE) in Brazil. The study indicated no relationship between accounting and market-based indicators and control variables and reporting quality. Aggarwal (2013) investigated the impact of the sustainability performance of a company on its financial performance. The study focused on listed Indian companies. The finding shows the twofold results of corporate sustainability influence on financial performance based on the indices for performance. The result indicated on one hand that corporate sustainability practices influence financial performance measures such as Return on Assets (ROA), Profit before Tax (PBT) and Growth in Total Assets (GTA) positively.

On the other hand, corporate sustainability influences financial performance, such as Return on Equity (ROE) and Return on Capital Employed (ROCE) negatively. The author concluded that corporate sustainability reporting has no significant association with firm performance. It was supported by the result of the study by Asuquo, Dada and Onyeogaziri (2018) on the effect of sustainability reporting on corporate performance of selected quoted brewery firms in Nigeria for the period 2012 - 2016. The authors used economic, environmental and social disclosures as proxies for sustainability reporting and Return on Assets (ROA) as a proxy for performance. The finding was that economic performance disclosure (ECN), environmental performance disclosure (ENV) and social performance disclosure (SOC) have no significant effect on return on asset (ROA) of the firms studied. Priyanka (2015) did a similar study using companies in India. The finding shows that sustainability reporting practices of companies in India have a negative impact on the performance of companies in the short run and a positive effect on the long term.

\section{3.1. The motivation for and Benefits of Sustainability Reporting}

Sustainability information conveys the company's economic, social and environmental impacts caused by its everyday activities to stakeholders. By so doing, it presents the firm's value and governance model and demonstrates the link between its strategies and its commitment to a sustainable global economy. External stakeholders need to understand the company's real value, its tangible and intangible assets. Companies can no longer operate at the neglect of society and the environment (Whetmen, 2018). Companies need to be transparent about the risks, opportunities and their performance to establish trust with stakeholders (INTOSAI WGEA, 2013). It is through sustainability reporting that they can gain knowledge relating to the risks and different opportunities available to them. Saridewi and Koesrindartot, (2014); Uwuigbe, (2011) posit that sustainability reporting can improve organizations' ability to understand and manage sustainability-related risks and help them better anticipate changing societal expectations. This knowledge can be used to inform and stimulate future practice (Corporate Citizenship, 2012). Reporting on sustainability issues is a recognized way of engaging and involving stakeholders in corporate practice (Corporate Citizenship, 2012), as they can play a role in identifying non-financial risks and opportunities for the organization. The involvement of stakeholders increases transparency, better decision making, and helps to build and maintain trust between the business and governments. 
Sustainability reporting has been found to improve the long term success of the reporting entity, one of the reasons for which investors are increasingly seeking to invest in the companies that follow good sustainability practices (Burhan \& Rahmanti, 2012).

Negative impacts of social, environmental and governance can be reversed through sustainable reporting, thereby improving and managing an organisation's reputation and brand loyalty. Thus it is no surprise that the majority of the reporters are large companies and firms having severe environmental impacts. (INTOSAI WGEA, 2013). It is used in this case as a medium to show compliance, demonstrate the corporate point of view, and promote corporate image (Corporate Citizenship, 2012).

Information is vital to the survival of every business. Sustainability reporting creates an information resource (Corporate Citizenship, 2012). It helps to gather and organize information to improve management systems and the quality of management information. As INTOSAI WGEA, (2013); Uwuigbe, (2011) noted, paying attention to sustainability can help to drive innovation, develop new market offerings and safeguard sustainable growth in the long run. Further, reporting can act as a tool for leadership, increase employee satisfaction and make organizations attractive to new employees (Aggarwal, 2013).

Sustainability reporting can be a tool to attain cost savings, because it encourages an organization to use natural resources more efficiently, improve process efficiency, and use recoverable resources (Saridewi \& Koesrindartot, 2014; Uwuigbe, 2011). It provides a framework for measurement and target setting of organizational goals (Corporate Citizenship, 2012). It helps companies to discover weaknesses, opportunities and set a new goal (Buniamin, Alrazi, Johari \& Abd-Rahman, 2011). Finally, sustainability reporting can be used to address the demand for more transparency and better accountability brought about by the global financial crises and the sustainability issues currently facing the world today (INTOSAI WGEA, 2013).

\subsubsection{Profitability and Sustainability Reporting}

Profitability is one of the main objectives of a business organization. Profit in this sense could be either accounting profit which refers to the excess of income over expenses for a particular period or economic benefit which in addition to the former also incorporates opportunity cost or forgone alternative of the business (Hofstrand, 2009). A firm's profitability is an indication of how efficiently the firm's resources are managed, and so it is of particular interest to several stakeholders (Nwude, 2004). Previous research studies have demonstrated that sustainability reporting affects a firm's profitability. Still, some firms are not sufficiently convinced that sustainability reporting can affect profit positively. Some firms reluctantly report on their sustainable activities to show compliance with regulation while others consider it is a waste of resources. A research carried out by Laskar (2019) found out that the association between profitability and sustainability reporting is positive and significant with South Korean firms but the Indian firms, it was negative. The further finding indicates that the relative impact of sustainability reporting is found to be significantly more in South Korea as compared with India. Considerable data abound which show that companies which do not act sustainably perform considerably worse than those who are doing so (Nordea Equity, 2017). A GRI study of 2600 executives and managers from companies around the world revealed that the percentage of companies reporting profit from the implementation of sustainability increased from $23 \%$ to $37 \%$ in one year. The finding also showed that the degree to which a company incorporates sustainability concerns into its business model correlates with an increase in profit.

\subsection{Theoretical Framework}

\subsubsection{Legitimacy Theory}

Legitimacy is a status that is an outcome of society's collective perception of the organization's operation. It is a social assessment or appraisal of corporate conduct that is considered acceptable, appropriate, or/and desirable (Zimmerman \& Zeitz, 2002; as cited in Lim, Wilmshurst \&Shimeld, 2010). Therefore, it is expected that firms will undertake acceptable behaviour or at least to be perceived as such so that they are perceived to be 'good' corporate citizens. Legitimacy is 'a generalized perception or assumption that the actions of an entity are desirable proper or appropriate within some socially constructed systems of norms, values, beliefs, and definitions' (Suchman, 1995 as cited in Lim et al., 2010). Theory of legitimacy asserts that the organization seeks to ensure that they are perceived as operating within the bounds and norms of their respective societies, that is they attempt to ensure, that outside parties perceive their activities as being 'legitimate.' These bounds and rules are not considered to be fixed but change over time, thereby requiring organizations to be responsive to the ethical environment in which they operate (Deegan \&Unerman, 2011 as cited in Ismail \& Haddow, 2014). According to this theory, it is essential to meet the societal norms and expectations to ensure the survival of a firm in the long-term (Lindblom, 1993 as cited in Aggarwal, 2013). The proponents of legitimacy theory argue that corporate social and environmental responsibility tends to reduce the risk of regulatory actions and boycotts by stakeholders and strengthens the firm's license to operate. (Aggarwal, 2013).

\subsubsection{Stakeholder Theory}

Stakeholders are 'groups and individuals who benefit from or are harmed by, and whose the right is violated or respected by corporate actions.' (Freeman, 1998 as cited in Branco \& Rodrigues, 2007). Post et al. (2002, p. 8) in Branco and Rodrigues (2007) defined the stakeholders of a company as the individuals and constituencies that contribute, either voluntarily or involuntarily, to its wealth-creating capacity and activities, and who are therefore its potential beneficiaries and risk bearers.' A company's stakeholders are those who supply critical resources, place something of value 'at risk,' and have sufficient power to affect its performance. In addition to shareholders, stakeholders include creditors, employees, 
customers, suppliers, and the communities at large. Stakeholder theory asserts that companies have a social responsibility that requires them to consider the interests of all parties affected by their actions. Management should not consider only its shareholders in the decision-making process but also anyone who is affected by business decisions. Proponents of this theory argue that it is relationships rather than transactions that are the ultimate sources of a company's wealth, and it is the ability to establish and maintain such relationships within its entire network of stakeholders that determines its longterm survival and success of the organisation (Branco \& Rodrigues,2007; Freeman, Wicks \& Parmar,2004).

\subsection{Hypotheses Development}

Recent researches on the subject matter have shown varying results. Burhan and Rahmanti (2012), discovered that sustainability reporting influences company performance partially. Only social disclosures influence company performance. Aondoakaa (2015), found that sustainability reporting has a significant positive impact on return on assets, return on equity, net profit margin and earnings per share, respectively, in Nigeria. Kasbun, Teh, and Ong (2016) found out that there is a positive association between sustainability reporting, economic, social, and environmental sustainability reporting and financial performance.

Mohammed, Zakaree, and Oladele (2016) examined the impact of corporate social responsibility disclosure on the financial performance of listed manufacturing firms in Nigeria. They found out that corporate social responsibility disclosures have a significant positive effect on EPS. This work intends to reconfirm these works. Therefore, the following hypotheses stated in null are used for the research

- $H_{01 a}$ : Social disclosures do not have a significant effect on ROE of listed manufacturing companies in Nigeria

- $H_{01 b}$ :Social disclosures do not have a significant impact on EPS of quoted manufacturing companies in Nigeria

- $H_{02 a}$ : Environmental disclosures do not have a significant impact on ROE of listed manufacturing companies in Nigeria

- $H_{02 b} \quad$ Environmental disclosures do not have a significant effect on EPS of quoted manufacturing companies in Nigeria.

- $H_{03 a}$ :Economic disclosures do not have a significant impact on ROE of listed manufacturing companies in Nigeria.

- $H_{03 b}$ :Economic disclosures do not have a significant impact on EPS of listed manufacturing companies in Nigeria

\section{Methodology}

\subsection{Research Design}

The research was analytical; the study employed the ex-post factor design because of the secondary data used which cannot be manipulated. Also the design was selected because it is suitable for studying events that have already taken place. A systematic design was chosen to determine the impact of the three pillars of sustainability reporting on the profitability of manufacturing firms. The researcher also made use of content analysis for data collection. The decision to use content analysis was to enable the researcher to extract both qualitative and quantitative information specified by the GRI from the annual reports of selected companies. The population of the study consists of all the 23 consumer goods manufacturing companies listed on the Nigerian Stock Exchange as at 31st December 2018. A judgmental sampling technique was adopted to select a total of 15 listed firms for this study; based on their market capitalization status and availability of 2009-2018 annual reports. It means that the companies that made up the sample were listed in the Nigerian Stock Exchange as at 2009 and were still listed as at 2018. Judgmental sampling technique was chosen to enable the researcher to derive the desired data for the study.

\subsection{Data Collection}

The study was conducted based on secondary data. The secondary data was collected from annual reports of the selected sample companies which are the most important documents companies use to communicate with their shareholders and other stakeholders. Sustainable disclosure performance (independent variables) score of the firms under study was obtained through the use of content analysis. These independent variables were measured by scoring index based on the Specific Standard Disclosures performance indicators provided in Global Reporting Initiative Guidelines G4 (GRIG4).

The disclosure performance index obtained was further used to determine the effect of the corporate sustainability reporting on firm performance employing a multiple regression model. The techniques used for data analysis are content analysis and multiple regressions. Multiple regression analysis was most advantageous to the study because it is employed to determine the impact of more than one independent variable on the dependent variable. Descriptive statistics were used to show the characteristics of the data collected.

\subsection{Definition of Operational Variables}

\subsubsection{Dependent Variable}

The dependent variables used as measures of company profitability were Return on Equity (ROE) and Earnings per Share (EPS) 
The formula of ROE:

$$
\begin{aligned}
& \mathrm{ROE}=\frac{\text { Profitafterinterestandtax }}{\text { Equity }} ; \\
& \mathrm{EPS}=\frac{\text { Profitafterinterestandtax }}{\text { ShareCapital }}
\end{aligned}
$$

Return on Equity and Earnings per Share are among the ratios for measuring business profitability. ROE and EPS are chosen because they show the proportion of company returns attributable to shareholders. Shareholders are the owners of a company limited by shares. It will be worthwhile to ascertain how sustainability reporting affect shareholders returns.

\subsubsection{Independent Variables}

Sustainability reports involve disclosure on the company's sustainability performance viewed from three dimensions. They are economics, environmental, and social aspects. These dimensions make up the three independent variables for this study. These are:

- Economic performance disclosures

- Environmental performance disclosures

- Social performance disclosures

According to the Global Reporting Initiative (2013), the economic dimension of sustainability concerns the organization's impacts on the economic conditions of its stakeholders and economic systems at local, national, and global levels. It does not focus on the financial status of the organization; the environmental dimension of sustainability looks at the organization's impact on living, and non-living natural systems, including land, air, water and ecosystems and the social aspect of sustainability refers to the effects the organization has on the social networks within which it operates.

These independent variables were measured by scoring index based on performance indicators provided in the Global Reporting Initiative Guidelines G4 (GRIG4) Specific Standard Disclosures. Global Reporting Initiative (GRI) Sustainability Guidelines on Economic, Environmental, and Social Performance is the most prominent current reporting guidelines (Burhan \& Rahmanti, 2012). Research conducted by Dincer (2011) in Burhan and Rahmanti (2012) also suggests adopting the GRI format as a CSR reporting model to be used by the firm for disclosing information.

A score of one (1) was awarded if an item was reported; otherwise, a score of zero (0) was awarded. Consequently, a firm could score a minimum of 0 and a maximum of four, twelve and thirty $(4,12$ \& 30) points on economic, environmental and social categories respectively. The formula used to calculate the index score is:

Index of CSR_GRI Disclosure Rate $=\frac{\sum_{k=0}^{k=1(\text { itemavailablable })}(k)(k)}{N=(\text { totalGRIDisclosureRequirement })}$

Where $\mathrm{N}$ is the total number of items expected to be reported by the firms based on GRI guidelines. Thus, it takes value 4 for economic, 12 for environmental and 30 for social. $\mathrm{K}$ is the sum of the scores of the actual disclosure, which takes value1 if a firm reports specific item in the categories of economics, environmental and social and 0 otherwise. Thus, the maximum value of the sum of $\mathrm{K}$ is 30 for the social, 4 for economics and 12 for environmental. Thus, the values of the Index of CSR_GRI Disclosure Rate range between 1 and 0 . The index of 1 suggests total disclosure (i.e. all items were disclosed) as required by GRI and the value 0 , shows that the firms did not disclose any items according to the GRI guideline. Values between 1 and 0 exclusive suggest partial disclosure.

\subsubsection{Model Specification}

The study adopted and modified the model specified in Burhan and Rahmanti (2012). The equation is presented below:

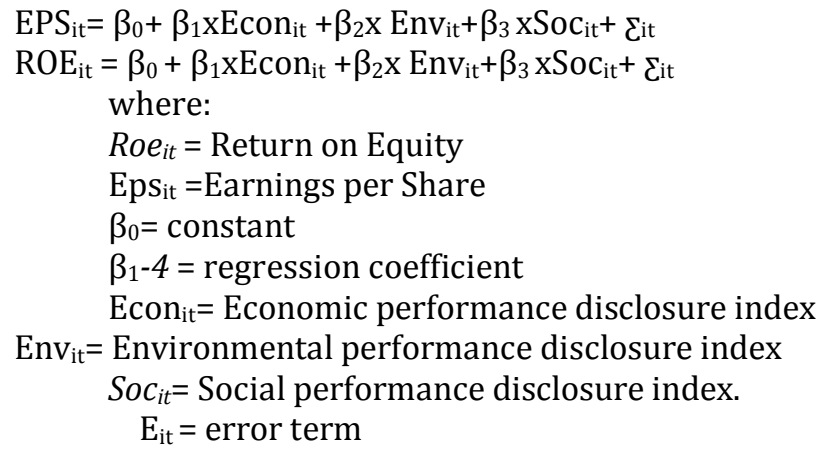

We modified Burhan and Rahmanti (2012) model in equation 1 and 2 by introducing lag of earnings per share and return on equity to obviate spurious results associated with time-series data. The variables EPS_1 and ROE_1 in equations 3 and 4 respectively are to act as a moderating variable to take care of autocorrelation.

$\mathrm{EPS}_{\mathrm{it}}=\beta_{0}+\beta_{1} \mathrm{xEcon} \mathrm{it}_{\mathrm{it}}+\beta_{2} \mathrm{x} \mathrm{Env}_{\mathrm{it}}+\beta_{3} \mathrm{xSoc}_{\mathrm{it}}+\beta_{4} \mathrm{EPS}_{\mathrm{it} \_}+\sum_{\mathrm{it}}$

$\mathrm{ROE}_{\mathrm{it}}=\beta_{0}+\beta_{1} \mathrm{XEcon}_{\mathrm{it}}+\beta_{2} \mathrm{X} \mathrm{Env}_{\mathrm{it}}+\beta_{3} \mathrm{XSoc}_{\mathrm{it}}+\beta_{4} \mathrm{ROE}_{\mathrm{it} \_} 1+\varepsilon_{\mathrm{it}}$

Where, 


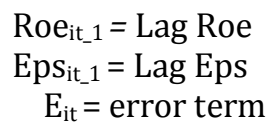

\section{Descriptive Statistics}

Using the SPSS, the researcher used the data and computed the mean, standard deviation, and variance, which form the descriptive statistics for both the dependent and the independent variables. The result of the computation is presented below.

\begin{tabular}{|c|c|c|c|c|c|}
\hline & $\mathbf{N}$ & Minimum & Maximum & Mean & Std. Deviation \\
\hline ECO & 150 & 0.0000 & 1.0000 & 0.7733 & 0.2135 \\
\hline ENV & 150 & 0.0000 & 0,8300 & 0.1327 & 0.2103 \\
\hline SOC & 150 & 0.0000 & 2.0000 & 0.3090 & 0.1896 \\
\hline ROE & 150 & -1.0100 & 1.1100 & 0.2036 & 0.2753 \\
\hline EPS & 150 & -16.8200 & 54.2600 & 3.3857 & 7.7648 \\
\hline $\begin{array}{c}\text { Valid N } \\
\text { (listwise) }\end{array}$ & 150 & & & & \\
\hline
\end{tabular}

Table 1: Descriptive Statistics

Note: This table provides summary statistics. ECO is the environmental disclosure; ENV is the economic performance disclosure; SOC is social performance disclosure; ROE is the return on equity; EPS is earnings per share, and N is a number of observations.

Table 1 shows that the mean value of economic performance disclosures is $77.33 \%$ with fair variability of 0.21 . This figure is high when compared to result for an environmental performance whose mean is $13.27 \%$ with the variability of 0.20 and social performance disclosures with mean $30.90 \%$ and standard deviation of 0.1896 . This means that most Companies disclose economic performance more than environmental and social performance.

\subsection{Pairwise Correlation Analysis}

Table 2 shows the correlation matrix for the variables of this study. First on Table 2 results (the upper-right diagonal reports for earnings per share -Pearson correlation coefficients in bold) show that only two sustainability performance variables (economic and environmental) are correlated with each other at the $1 \%$ significance level, which indicates that they are necessary measures. Also, the variables of interest, earnings per share is significantly and positively correlated with economic and environmental performance indicators at the 1\% significance, while marginal significance $(p=0.088<0.10)$ exists between earnings per share and social performance disclosures. Second on Table 2 results (the lower-left diagonal- return on equity- Pearson correlation coefficients) of the Pearson coefficients shows that return on equity has a significant and positive correlation with all the sustainability performance variables at the $1 \%(\mathrm{p}<0.01)$ significance level, which suggests that the higher the sustainability performance, the higher the return on equity.

\begin{tabular}{|c|c|c|c|c|}
\hline \multicolumn{2}{|c|}{ EPS } & ECO & ENV & SOC \\
\hline \multirow{2}{*}{ ROE } & 1. & $0.266^{* *}$ & $0.388^{* *}$ & $0.310^{* *}$ \\
\cline { 2 - 5 } & & $(0.001)$ & $(0.000)$ & $(0.000)$ \\
\hline \multirow{2}{*}{ ECO } & $0.219^{* *}$ & 1. & $0.317^{* *}$ & 0.155 \\
\cline { 2 - 5 } & $(0.007)$ & & $(0.000)$ & $(0.058)$ \\
\hline \multirow{2}{*}{ ENV } & $0.254^{* *}$ & $0.317^{* *}$ & 1. & $0.346^{* *}$ \\
\cline { 2 - 5 } & $(0.002)$ & $(0.000)$ & $0.346^{* *}$ & $(0.000)$ \\
\hline \multirow{2}{*}{ SOC } & 0.140 & 0.155 & $(0.000$ & 1. \\
\cline { 2 - 5 } & $(0.088)$ & $(0.058)$ & 150 & 150 \\
\hline
\end{tabular}

Table 2: Correlation Matrix

This table presents the Pearson correlation matrices. The upper-right diagonal reports for earnings per share Pearson correlation coefficients in bold, and the lower-left diagonal- return on equity- Pearson correlation coefficients. The numbers reported in parentheses are p values. *. Correlation is significant at the 0.05 level (2-tailed). EPS is the earnings per share; ROE is the return on equity; ECO is the economic performance disclosure; ENV is the environmental performance disclosure; SOC is the social performance disclosure; $\mathrm{N}$ is the number of observations.

\subsection{Multicollinearity Analysis}

The result of the pairwise correlation analysis in Table 2 reveals a positive correlation between all the independent variables (ECO, ENV, and Soc) and the dependent variables (EPS and ROE). Hence, some issues are commonly related to the behaviour between endogenous variables. Therefore, a further check of collinearity is required. We used a robustness check by conducting the test for multicollinearity using the variance inflation factor (VIF) and tolerance. Table 3 presents the Variance Inflation Factor (VIF). 


\begin{tabular}{|c|c|}
\hline Variables & VIF \\
\hline ECO & 1.1659 \\
\hline ENV & 1.2689 \\
\hline SOC & 1.1737 \\
\hline MVIF & 1.2028 \\
\hline
\end{tabular}

Table 3: Variance Inflation Factor

Table 3 shows that VIF $1.2028<5$ as propagated (Aondoakaa, 2015). This indicates the absence of multicollinearity problem that might affect the accuracy and reliability of the result and ultimately, the findings and conclusions generated from this study.

\subsection{Regression Results and Discussion of Findings}

In this section, regression results are presented. First, Table 5 below shows the summary of the regression result of the Earnings per share (EPS) reaction to the Sustainability Reporting indicators, economic performance disclosure, environmental performance disclosure, and social performance disclosure index using model 1.

\begin{tabular}{|c|c|c|c|c|c|c|}
\hline Estimator & Model 1(EPS) & & & Model 3(EPS) & & \\
\hline Variable & Coef & Std Error & Prob & Coef & Std Error & Prob \\
\hline ECO & 5.4367 & 2.8312 & $0.0568^{* *}$ & 0.7712 & 2.3103 & 0.7390 \\
& $(1.9202)$ & & & $0.3338)$ & & \\
\hline ENV & 10.1379 & 3.0261 & $0.0010^{*}$ & 6.3375 & 2.4361 & $0.0103^{*}$ \\
& $(3.3500)$ & & & $(2.6014)$ & & \\
\hline SOC & 7.8490 & 2.4353 & $0.0161^{*}$ & 3.8350 & 2.5963 & 0.1418 \\
& $(2.4353)$ & & & $(1.4770)$ & & 0.5973 \\
\hline EPS_1 & & & & $(9.3769)$ & 0.0637 & $0.0000^{*}$ \\
& & & & -1.2555 & 1.8680 & 0.5026 \\
\hline Cons & -4.5896 & 2.3015 & $0.0480^{* *}$ & $(-0.6721)$ & & \\
& $(-1.9941)$ & & & 0.5064 & & \\
\hline $\mathrm{R}^{2}$ & 0.2059 & & & 0.4927 & & \\
\hline Adj R & 0.1895 & & & 36.9457 & & \\
\hline F-Statistic & 12.6194 & & & $0.0000^{* * *}$ & & \\
\hline Prob. F & $0.0000^{* * *}$ & & & 2.0076 & & \\
\hline DW & 0.8923 & & & & & \\
\hline
\end{tabular}

Table 4: Regression Result of Sustainability Reporting Indicators and Earnings Per Share

Table 5 describes the relationship between sustainability performance reporting and profitability of a sample of Nigerian firms quoted on the Nigerian Stock Exchange in the period 2009 to 2018. The table shows the regression coefficients (Coeff.) $t$-values, total explanatory power (adj. R2), F-statistics, the probability of $F$, number of observation (n) for the total sample. EPS is the earnings per share; ECO is the economic performance disclosure; ENV is the environmental performance disclosure; SOC is the social performance disclosure; EPS_1 is lag pf earnings per share. Note: $\quad *$ significant at the $1 \%$ level, ${ }^{* *}$ significant at the $5 \%$ level, ${ }^{* * *}$ significant at $10 \%$ level

Model Specifications:

Model 1: $\mathrm{EPS}_{\mathrm{it}}=\beta_{0}+\beta_{1} \mathrm{xEcon}$ it $+\beta_{2} \mathrm{x} \mathrm{Env}_{\mathrm{it}}+\beta_{3} \mathrm{xSoc}$ it $+\varepsilon_{\mathrm{it}}$

Model 3: $\mathrm{EPS}_{\mathrm{it}}=\beta_{0}+\beta_{1} \mathrm{xEcon}{ }_{\mathrm{it}}+\beta_{2} \mathrm{X} \mathrm{Env}_{\mathrm{it}}+\beta_{3} \mathrm{xSoc} \mathrm{Cit}_{\mathrm{it}}+\beta_{4} \mathrm{EPS}_{\mathrm{it} \_1}+\sum_{\mathrm{it}}$

Model 1 regression result in Table 5 revealed a possible problem of independence of the error term as was indicated by the Durbin-Watson statistics $(0.8923)$. Concerning the issue of autocorrelation between the residual of the data used in this study, we introduced the variables Lag EPS (EPS_1) in model 3 and Lag ROE (ROE_1) in model 4 to act as moderating variables to take care of the autocorrelation related issues.

Hence, the inclusion of the moderating (EPS_1) in model 3 normalized the data for accurate data analysis. Model 3 regression result in Table 5, indicates the D-W statistic of 2.0076. This shows that there is a positive autocorrelation and further suggests that the statistic favours the accuracy and reliability of the results generated based on model 3 regressionresult of the earnings per share (EPS) reaction to the sustainability reporting indicators- economic performance disclosure, environmental performance disclosure, and social performance disclosure index. Our approach is in line with Aondoakaa (2015). Therefore, for brevity and clarity, our hypothesis testing, discussion of findings and conclusion are restricted to regression results of models 3 and 4 in Tables 5 and 6.

Table 5 shows the multiple regression analysis on earnings per share reactions to the combination of sustainability reporting indicators (economic performance disclosure, environmental performance disclosure, and social performance disclosure) and moderating variable (lag EPS). Concerning the EPS reaction to the combination of sustainability reporting indicators and EPS_1, our results of model 3 in Table 5 revealed that both the independent and moderating variable is significant with a 51\% reliability, with F-statistic 36.9457 and Prob. F 0.0000 (at the $1 \%$ significance level $(\mathrm{p}<0.01)$ ). This implies that $51 \%$ of the variation of EPS is explained by variation in sustainability performance disclosures; other factors explain the rest. Interestingly, the intercept of the regression is, correctly signed 
per the prior expectation, implying first that sustainability reporting is contributing positively and significantly to the profitability of consumer goods manufacturing companies listed on the Nigerian Stock Exchange. The finding in the context of this study is in tandem with the views of Burhan \& Rahmanti, 2012) that investors are increasingly seeking to invest in the companies that follow good sustainability practices. Also, the result agrees with the evidence provided by Aondoakaa (2015) and Kasbun et al. (2016).

However, Table 5, shows that the coefficient and T-value of ECO is 0.7712 and 0.3338 respectively and insignificant at the $5 \%$ level, which is consistent with our null hypothesis $\left(\mathrm{H}_{3}\right)$, economic disclosures do not have a significant impact on the profitability of listed manufacturing companies in Nigeria. This result is in tandem with the findings of Burhan and Rahmanti (2012)

On the other hand, ENV with the coefficient of 6.3375, T-value of 2.6014 and P-value of $0.0103(\mathrm{P}<0.01)$ significantly and positively contributed to the sampled companies' earnings per share (EPS). The result provides strong evidence against our hypothesis $\left(\mathrm{HO}_{2}\right)$ that environmental disclosures do not have a significant impact on the profitability of listed manufacturing companies in Nigeria. Therefore, we accept the alternative hypothesis, implying that environmental disclosures of listed manufacturing companies in Nigeria have impacted positively and significantly on their financial performance. This finding supports the legitimacy theory (Aggarwal, 2013) and stakeholders' theory (Branco \& Rodrigues, 2007). Also, provided evidence to the views of proponents of this theory that it is relationships rather than transactions that are the ultimate sources of a company's wealth, and it is the ability to establish and maintain such relationships within its entire network of stakeholders that determines its long-term survival and success of the organization (Branco \& Rodrigues, 2007; Freeman, Wicks \& Parmar,2004).

The regression result of model 3 in Table 5, further revealed that SOC has no significant (p-value $>10 \%)$ impact on the profitability of the listed manufacturing companies of Nigeria Stock Exchange. Based on the p-value of 0.1418, we accept null hypothesis 1 (HO1), social disclosures do not have a significant effect on the profitability of listed manufacturing companies in Nigeria. The finding agrees with Saridewi and Koesrindartot (2014), who reported that there was no significant relationship between social disclosure and financial performance. On the other hand, this result contradicts the finding by Burhan and Rahmanti (2012) that only social disclosures influence company performance. Moreover, lag EPS results in Table 5 shows a positive and significant (at the $1 \%$ significance level) influence on the relationship that exists between the earnings per share (EPS) and the sustainability reporting indicators.

\begin{tabular}{|c|c|c|c|c|c|c|}
\hline Estimator & Model 2(ROE) & & & Model 4(ROE) & & \\
\hline Variable & Coef & Std Error & Prob & Coef & Std Error & Prob \\
\hline ECO & $\begin{array}{c}0.1959 \\
(1.8208)\end{array}$ & 0.1075 & $\begin{array}{c}0.0707^{*} \\
* *\end{array}$ & $\begin{array}{c}0.0176 \\
(0.2139)\end{array}$ & 0.1032 & 0.3009 \\
\hline ENV & $\begin{array}{c}0.2460 \\
(2.1395)\end{array}$ & 0.1149 & $\begin{array}{c}0.0341^{*} \\
*\end{array}$ & $\begin{array}{c}0.1687 \\
(1.5412)\end{array}$ & 0.1095 & 0.1254 \\
\hline SOC & $\begin{array}{c}0.0743 \\
(0.6073)\end{array}$ & 0.12247 & 0.5446 & $\begin{array}{c}0.03264 \\
(0.2818)\end{array}$ & 0.1185 & 0.7785 \\
\hline ROE_1 & & & & $\begin{array}{c}0.3527 \\
(4.5021)\end{array}$ & 0.0783 & $0.0000^{*}$ \\
\hline Cons & $\begin{array}{c}-0.0034 \\
(-0.0397)\end{array}$ & 0.0874 & 0.9684 & $\begin{array}{c}0.01769 \\
(0.2139)\end{array}$ & 0.08272 & 0.8309 \\
\hline $\mathrm{R}^{2}$ & 0.0882 & & & 0.1982 & & \\
\hline Adj $\mathrm{R}^{2}$ & 0.06694 & & & 0.1750 & & \\
\hline F-Statistic & 4.7079 & & & 8.8989 & & \\
\hline Prob. F & $0.0036^{*}$ & & & $0.0000^{*}$ & & \\
\hline DW & 1.3757 & & & 2.1438 & & \\
\hline
\end{tabular}

Table5 describes the relationship between sustainability performance reporting and profitability of a sample of Nigerian firms quoted on the Nigerian Stock Exchange in the period 2009 to 2018. The table shows the regression coefficients (Coeff.) t-values, total explanatory power (adj. $\mathrm{R}^{2}$ ), F-statistics, the probability of $\mathrm{F}$, number of observation (n) for the total sample. ROE is the return on equity; ECO is the economic performance disclosure; ENV is the environmental performance disclosure; SOC is the social performance disclosure; ROE_1 is the lag return on equity. Note: $*$ significant at the $1 \%$ level, ${ }^{* *}$ significant at the $5 \%$ level, ${ }^{* * *}$ significant at $10 \%$ level

Model Specifications:

Model 2: $\mathrm{ROE}_{\mathrm{it}}=\beta_{0}+\beta_{1} \mathrm{xEcon}$ it $+\beta_{2} \mathrm{x} \mathrm{Env}_{\mathrm{it}}+\beta_{3} \mathrm{xSoc} i \mathrm{it}+\sum_{\mathrm{it}}$

Model 4: $\mathrm{ROE}_{\mathrm{it}}=\beta_{0}+\beta_{1} \mathrm{xEcon} \mathrm{it}_{\mathrm{it}}+\beta_{2} \mathrm{x} \mathrm{Env}_{\mathrm{it}}+\beta_{3} \mathrm{xSoC_{it }}+\beta_{4} \mathrm{ROE}_{\mathrm{it} \_1}+\sum_{\mathrm{it}}$

Regarding the return on equity and anchoring our findings on model 4 in Table5, the multiple regression analysis on return on equity reactions to the combination of sustainability reporting indicators and moderating variable (ROE_1) revealed a mixed result. Concerning the ROE, model 4 in Table5 indicates that both the independent and moderating variable is significant, with an about $20 \%$ reliability, with F-statistic 8.8989 and Prob. F 0.0000 (at the $1 \%$ significance level $(\mathrm{p}<0.01)$ ). This implies that $20 \%$ of the variation of ROE is explained by variation in sustainability performance disclosures; other factors explain the rest. However, and surprisingly, all the coefficients and t-values of sustainability performance disclosures indices are individually insignificant but positive, which suggests that sustainability performance 
disclosures are insignificant in explaining variations in the return on equity although the intercept is correctly signed which implies the higher the sustainability performance disclosures within the companies, the higher the return on equity.

\section{Conclusion, Limitations and Recommendations}

We investigate how sustainability reporting impact on company profitability. The purpose is to determine the effect of all the three pillars of sustainability reporting on sampled company's profitability. Towards this end, we exploit the setting in Nigeria, an emerging economy, where organizations may be unsure of the benefit of sustainability reporting and see nothing specific to gain from publishing sustainability reports. Consistent with prior research, we generally find that sustainability reporting has a positive influence on company profitability. Specifically, we find that environmental disclosure has a positive and significant impact on the company's profitability. Interestingly the magnitude and significance of the positive earnings per share reaction to environmental disclosure practices are positively related to both legitimate and stakeholders theories confirming that investors and other stakeholders are interested in the activities of firms within the environment. This implies that an increase in sustainability reporting would lead to an increase in profitability.

This work has added to the available literature on sustainability reporting in Nigeria by looking at how sustainability reporting as a whole influence company performance and how each of the three aspects of sustainability reporting (social, environmental and economic disclosures) influenced company profitability in Nigeria. Furthermore, the model used was modified to include a moderating variable to take care of autocorrelation.

\subsection{Limitations of the Study}

There are two significant limitations in this study that future research can address. First, the study concentrated only on manufacturers of consumer goods in Nigeria. This means that the result of the study cannot apply to other manufacturing firms. Further research in sustainability reporting should focus on different groups of manufacturing firms and in addition, may consider evaluating the impact of Sustainability Reporting on other performance measures like the share of the market, financial leverage and firm size. Secondly, most of the firms were not actively involved in voluntary disclosure of sustainability reporting because there were no codes guiding companies sustainability reporting. Every company reported what it wanted to communicate. During the period covered by this research, Nigeria had not issued any sustainability code making it mandatory for all companies in the country. The Nigerian Stock Exchange issued a code on sustainability reporting with effect from 1 January 2019. Further studies on this or related topics may produce different result because many companies would have been sincerely involved in applying the code requirements in reporting.

\subsection{Recommendations}

Business organisations are encouraged to publish useful sustainability reports. This is because good sustainability reporting practice results in better profitability for the company. Availability of sustainability guidelines issues by the Securities and Exchange Commission will be a good reference point.

The government should encourage companies to publish sustainability reports. There are currently no legislative requirements in Nigeria for companies to prepare and publish sustainability reports. Regulatory authorities like the Corporate Affairs Commission and the legislative arm of government should put in place regulations that encourage Sustainability Reporting.

Local communities where these companies operate and other stakeholders like employees and social and environmental non-governmental organizations must demand Sustainability Reporting to meet their information needs and help them hold companies to account for not only economic performance but also environmental and social performance as they affect them.

In addition to the above, there is a need for public enlightenment on what sustainability reporting is all about. This is to equip stakeholders with necessary information on what to expect and demand from published sustainability reports. The data will enable them to appraise companies based on the quality of their sustainability reports

There is need for continuous professional training on sustainability reporting. This will enable professionals, especially accountants, to make better input with regards to sustainability reporting.

More research works are needed to increase the literature available on sustainability reporting in Nigeria. This would provide more insight into the subject matter and more solutions to sustainability problems facing society.

\section{References}

i. Adediran, S.A. \& Alade, S. O. (2013). The Impact of Environmental Accounting on Corporate Performance inNigeria. European Journal of Business and Management, 5(23).

ii. Ademigbuji, A. (2014, April 14). Revealing It All in Sustainability Reporting. The Nation. Retrieved from www.nationonlineng.net

iii. Aggarwal, P. (2013) Relationship between Environmental Responsibility and Financial Performance of Firm: A Literature Review, IOSR Journal of Business and Management, 13(1), 13-22.

iv. Aggarwal, P. (2013). Impact of Sustainability Performance of company on its Financial Performance: A Study of Listed Indian Companies, Global Journal of Management and Business Research $\quad$ Finance, 13(11), 61 - 70.

v. Ali, A., Haitham, N., Nilesh, K. (2018). The Impact of Sustainability Practices on Corporate Financial Performance: Literature Trends and Future Research Potential, Sustainability, 10(2), 494 - 519.

vi. Aondoakaa, K. (2015). Impact of Sustainability Reporting on Corporate Performance of Selected Quoted Companies in Nigeria (thesis). Retrieved from University of Nigeria Virtual Library 
vii. Ariel, C. P. and Giulia, C. (2019). What investors actually want from sustainable data, Greenbiz, greenbiz.com

viii. Asuquo, T. A., Dada, E. T. and Onyeogaziri, U. R. (2018). The Effect of Sustainability Reporting on Corporate Performance of Selected Quoted Brewery Firms in Nigeria, International Journal of Business \&Law Research, 6(3), $1-10$.

ix. Branco, M. C. \& Rodrigues, L. L. (2007).Positioning Stakeholder Theory within the Debate on Corporate Social Responsibility. Electronic Journal of Business Ethics and Organization Studies.12(1).

x. Buallay, A. (2019). Sustainability Reporting and Firms Performance: Comparative Study between Manufacturing and Banking Sectors, International Journal of Productivity and Performance Management, $69(3), 431 \quad-445$, https://doi.org/10.1108/IJPPM - 10 -2018 - 0371

xi. Buniamin, S., Alrazi, B., Johari, N. H. \&Abd Rahman, N. R. (2011). Corporate Governance Practices and Environmental Reporting of Companies in Malaysia: Finding Possibilities of Double Thumbs Up.JurnalPengurusan, 32, 55-71.

xii. Burhan, A.H.N. \& Rahmanti, W. (2012). The Impact of Sustainability Reporting on Company Performance, Journal of Economics, Business, and Accountancy Ventura, 15(2), 257 - 272.

xiii. Ching, H. Y., Gerab, F. and Toste, T. H. (2017). The Quality of Sustainability Reports and Corporate Financial Performance: Evidence from Brazilian Listed Companies, Journal of Indexing \& $\quad$ Metrics, $1 \quad-\quad 9 . \quad$ DOI: 10.117712158244017712027

xiv. Corporate Citizenship. (2012). Adding Value Through Sustainability Reporting. Corporate Citizenship.

$x v$. Dibia, N. O.\& Onwuchekwa. J. C. (2015).Determinants of Environmental Disclosures in Nigeria: A Case Study of Oil and Gas Companies. International Journal of Finance and Accounting, 4(3), 145-152.

xvi. Freeman, R. E., Wicks, A. C. \& Parmar, B. (2004). Stakeholder Theory and 'The Corporate Objective Revisited'. Organization Science, 15(3), 364-369. DOI 10.1287/orsc.1040.0066

xvii. Global Reporting Initiative, (2013). G4 Sustainability Reporting Guidelines: Reporting Principles and Standard Disclosures. Global Reporting Initiative

xviii. Global Reporting Initiative, (2013). Embrace Sustainability (reporting) and Profit, MIT SMR report, globalreporting.org

xix Hofstrand D. (2009). Understanding Profitability. Retrieved from https:// www.extension.iastate.edu/agdm/wholefarm/html/c3-24.html

xx. International Accounting Standards Board (2013). IASB Signs a Memorandum of Understanding with IIRC. Retrieved from www.ifrs.org on 12th February 2017

xxi. International Organization for Standardization (2010). ISO 26000- Social Responsibility. Retrieved from http://www.iso.org/iso/home/standards/iso26000.htm

xxii. INTOSAI Working Group on Environmental Auditing (2013). Sustainability Reporting: Concepts, Frameworks and the Role of Supreme Audit Institutions. INTOSAI WGEA.

xxiii. Ismail I. K. \& Haddaw A. A. (2014). The Impact of The Theory of Legitimacy on The Disclosure of Organizations in Jordan Using A Linear Regression Model. European Journal of Business and Management, 6(16).

xxiv. Kasbun N. F., Teh B. H. \& Ong T. S. (2016). Sustainability Reporting and Financial Performance of Malaysian Public Listed Companies. Institutions and Economics, 8(4), 78-93.

xxv. Laskar, N. (2018). Impact of Corporate Sustainability Reporting on Firm Performance: an empirical examination in Asia, Journal of Asian Business Studies, 12(4), 571 - 593, DOI: 10.1108/JABS- $\quad 11-\quad 2016-0157$

xxvi. Laskar, N. (2019). Does Sustainability Reporting Enhance Firm Profitability? A study of selected companies from India and South Korea, Indian Journal of Corporate Governance,https//doi.org/ 10.1177/0974686219836528

xxvii. Lim, S.M., Wilmshurst, T. \&Shimeld, S. (2010) Blowing in The Wind Legitimacy Theory. An Environmental Incident and Disclosure. (p. APIRA 2010)

xxviii. Mohammed, N. A., Zakaree, S. and Oladele, O. K. (2016). Corporate Social Responsibility Disclosures and Financial Performance of Listed Manufacturing Firms in Nigeria. Research Journal of Finance and Accounting, 7(4).

xxix. Nordea Equity Research (2017). ESG: Going green and Coming Clean, Nordic Sustainable Finance Conference held in Stockholm, Nordic Region, organized by Nordea Corporate \& Investment Banking on Friday 22, September 2017

xxx. Nur, F. K., Boon, H. T., and Tze, S. O. (2016). Sustainability Reporting and Financial Performance of Malaysian Public Listed Companies, Institutions and Economies, 78 - 93.

xxxi. Nwude, C. E. (2004). Basic Principle of Financial Management- A first Course. ChukeNwabude Nigeria, Enugu.

xxxii. Onyali, C. I., Okafor, T. G. \& Egolum, P. (2014). An Assessment of Environmental Information Disclosure Practices of Selected Nigerian Manufacturing Companies. International Journal of Finance and Accounting,3(6), 349-355.

xxxiii. Priyanka, G. (2015) Impact of Sustainability Reporting on Firm Performance of Companies in India, International Journal of Marketing and Business Communication, 4(3), 1 - 8. DOI:10.21863/ijmbc/2015.4.3.018

xxxiv. Robert, G. E. and Svetlana, K. (2019). The Investor Revolution, Harvard Business Review, hbr.org

xxxv. Saridewi, P.N, \& Koesrindartoto, D.P (2014). The Link between Social, Environmental to Financial Performances of Companies in Indonesia .p. International Conference on Trends in Economics, Humanities and Management (ICTEHM'1) Pattaya (Thailand)

xxxvi. Sarumpaet, S. (2005). The Relationship between Environmental Performance and Financial Performance of Indonesian Companies. Jurnal Akuntansi \& Keuanga, .7(2), 89- 98.

xxxvii. Uwuigbe, U. (2011). An Empirical Investigation of The Association Between Firms' Characteristics and Corporate Social Disclosures in The Nigerian Financial Sector. Journal of Sustainable Development in Africa,13(1). 
xxxviii. Uwuigbe, U., Teddy, O., Uwuigbe, O. R. (2018). Sustainability Reporting and Firm Performance: A Bi-Directional Approach, Academy of Strategic Management Journal, 17(3), 1 - 16.

xxxix. Whetman, L. (2018). The Impact of Sustainability Reporting on Firms Profitability, Undergraduate Economic Review, 14(1), 1 - 21. 